\title{
THE EFFECT OF APPLYING SOCRATIVE ON STUDENTS' READING ABILITY
}

\author{
Riryn Fatmawaty, Sofi Nurhidayatus Sholihah \\ fatmawatyriryn@gmail.com, sofinhs07@gmail.com \\ English Language Education Department, Faculty of Teacher Training and Education, Universitas Islam \\ Lamongan
}

\begin{abstract}
This study aimed to determine the impact of the application of socrative to the reading ability of students in industrial 4.0 era, where anything was done using the internet and computers. The method used in this study was the pre-experimental type One Group Pretest-Posttest. This method used a class that was used as the object of research. This research was conducted at SMK 1 Baureno located on Jl. Raya Kepohbaru Department No. 258, Baureno, Plumbungan, Bojonegoro. The object of this research was the $10^{\text {th }}$ grade computer and network engineering students at SMK 1 Baureno. The number of students was 34 consisting of 17 male students and 17 female students. This research was conducted on February 5 through March 11, academic year 2019/2020. There were three activities carried out, namely pretest, treatment and posttest. The hypothesis accepted in this study was the alternative hypothesis $(\mathrm{Ha})$. Because the results of this study indicated that the t-test of 34 students was 17,07 with a significant level of t-table 0,05. This mean that there were differences in the ability of students before and after treatment was given. And from the results of questionnaires that had been done that $10^{\text {th }}$ grade students of computer and network technique at SMK 1 Baureno prefered to read online (using socrative) rather than reading offline.
\end{abstract}

Keywords: Reading ability, socrative

\section{INTRODUCTION}

Reading is a simple thing but it is often difficult for many people to do. Reading is an easy activity to do but often it has become a habit. Many people interpret that reading is a boring activity and just a waste of time. Especially in this day and era, namely in industrial 4.0 era where everything has been replaced by internet technology, computers or robots. Everything can be added into visuals that are more attractive to people who make people less interested in reading.
Nowadays, reading interest for teenagers, especially students, is decreasing, for example, when they read English reading. They will only immediately see the end of the reading without reading how the process happens when getting that conclusion. Because they think that reading is boring especially in English where they do not know how to read the vocabulary and they do not understand the meaning of the reading which makes them lazy to read English reading. 
In this 4.0 industry era, many students are not interested in reading books but they are more interested in reading through their smart phones.

Therefore, the writer wants to follow the times by applying socrative to the learning levet at SMKN 1 Baureno. Socrative is a student response system that allows teachers to make quizzes or interactive games and involve students directly or in real time. With the existence of socrative can facilitate the performance of not only students but also teachers. The teacher can monitor facilitate the performance of not only students but also teachers. The teacher can monitor all student activities when exams use this socrative. Although there are students who are unable to attend the exam. These students can take the exam wherever they are with supervision from the remote teacher. Because the teacher as a controller in this socrative.
Socrative is very effective and efficient to be applied in Bojonegoro, especially in urban areas. Even in schools, villages can use social media even though their scoll does not have a computer. Because socrative can be used not obly through computers but also cellphones. Therefore the writer is very supportive if this socrative can be applied throughout the Baureno vocational School.

Based on the background of the study above the problems are "is there any effect of socrative for tenth grade computer and network echnique students' reading ability at SMKN 1 Baureno" and "do tenth grade computer and network technique students at SMKN 1 Baureno prefer reading or online examination (using socrative) than reading or offline examination (using paper)".

The objectives of the study in this research is to get wheter the socrative is effective for tenth grade computer and network technique students' reading 
ability at SMKN 1 Baureno and to find out the choice of the tenth grade computer and network technique students between using socrative or paper at SMKN 1 Baureno.

According to Soedarso (2010: 4) reading is a complex activity by directing a large number of separate actions. Reading as an activity which includes the introduction of written symbols or sound symbols. Language acts as a stimulus to remember the meanings that were built on past experiences and arrange these new meanings by manipulating the concepts of the reader.

Reading can also be considered as a process to understand what is implied in what is written, that is understanding the meaning contained in the written words. The meaning of reading does not lie on the written page but on the reader's mind. Thus the meaning will change, because each reader has a different experience that is used as a foll to interpret these words (Harjasujana in Sumendar, 2008: 32-35).
Reading activities include 3 basic skills, namely recording, decoding, and meaning. Recording refers to words and sentence, then associate them with the sounds in accordance with the writing system used. The decoding process refers to the process of translating a series of graphics into words. While meaning is a process of understanding meaning that takes place from the level of understanding, interpretative, creative, and evaluative understanding. The recording and decoding process takes place in early grade students, while the meaning is more emphasized in high classes (Farida Rahim, 2008: 2).

Socrative one of the e-learning applications that can be used in learning based on ICT (Information Communication Technology). Socrative is a student response system that allows the teacher to make quizzes or interactive games and involve students directly or inreal time (Guraru, 2013). 
Furthermore, Chotijah (2016) states that e-learning media socrative is a product in processing material.

In socrative there are five menus, namely:

\section{Launch}

The launch feature there will be several choice such as quiz, space race, ticket excit and quick question in the form of multiple choices, true or false and short answer.

\section{Quizzes}

This menu serves to create quizzes or questions.

\section{Rooms}

This menu serves to create a room that is in the sense of making a group for students. In this menu they can see how many students join the teacher account.

\section{Reports}

This menu serves to display the history or all activities that they do in the socrative.

\section{Results}

This menu has a function to give the final results of students' scores after working on the tests given by the teacher. They can get students report by clicking finish, there will be three choices, namely get reports, view chart, and to launch. The report can be sent via email or downloaded directly.

The researcher has similar topic with this research. It is conducted by Hartini Ervi Astutik “The Effectiveness of English Morning Conversation in Teaching Vocabulary Matery”, the result of her research is that the English Morning Conversation effects for the students' vocabulary.

Based on the explanation above, the research is the interested in the effect of applying socrative for the tenth grade students of SMKN 1 Baureno. Furthermore, this research is conducted with the purpose to know the effect of after and before applying socrative for the students. 
controlled conditions. The controlled

\section{RESEARCH METHOD}

The method used in this study is the design method of One Group PretestPosttest design method which is a form of pre-experimental design. One Group Pretest-Posttest design used a pre-test before being treated, and then a post-test after being treated. Using this design, researcher can compare conditions before being treated and after being treated.

The sample of this research is Computer and Network Technique tenth grade students as the experimental class. The sampling technique uses quota sampling technique. Sugiyono (2016: 85) states quota sampling is a technique for determining samples from populations that have certain characteristics to the desired amount (quota).

This research is an experimental research. Experimental research is research that is used to look for differences in certain treatments for others under condition referred to is the existence of the results of the study being converted into numbers, for the analysis used using statistical analysis (Sugiyono, 2016: 72).

The experimental research method can be interpreted as a research method used to look for the effect of certain treatments on others under controlled conditions (Sugiyono, 2016: 72).

This research is pre-experimental designs because this design is not a real experiment because there are still external variables that influence the formation of the dependent variable. So the results of experiments which are dependent variables are not solely influenced by independent variables. This can occur, because there are no control variables, and the sample is not chosen randomly.

Sugiyono (2016: 73) states there are four kinds of experimental design. Those are pre-experimental design, trueexperimental design, factorial design, and quasi experimental design. In this research 
the researcher uses pre-experimental, which is called one group pretest-posttest. The pre-test is intended to see the reading ability of the students before treatment while the post-test is administrated to know the influence of the treatment. With the formula used is as follow:

$$
t_{o=\frac{M D}{S E_{M D}}}
$$

The instruments used in this reserach are test and questionnaire. The test are pre-test and post-test. Each contains 25 questions. Pre-test is given at the beginning of the meeting and post-test is given after being treated. The second instrument is questionnaire. Questionnaire is for supproting data. The writer makes precentage of each question in this questionnaire. The questionnaire used is the Guttman scale type. Measurement sclae with this type, will get a firm answer, which is "Yes or No", "True or False". Research using the Guttman scale is done if the writer wants to get a firm answer to a problem being asked. Guttman scale can be made in the form of multiple choice. In addition, it can also be made in the form of a checklist. The answer can be made the highest score one and lowest zero.

\section{FINDINGS AND DISCUSSION}

Based on the teaching and learning process, the researcher collected the data throughout the study. Data presentation showed about the results of the pre-test and post-test. The test results show the influence of teaching reading (present continuous) using socrative at SMKN 1 Baureno.

\section{The Result of Pre-test}

Pre-test was a test that was applied before being given treatment. The pre-test was attended by 34 students. The researcher gave 25 questions and the writer did not give any action to the students. So the results of the pre-test are students' original ability before getting the material or the treatment from the researcher. The results of pre-test was four students got the higest score. The score 
was more than 75 . The result og total pre-

test score was 2004 of 34 students. The mean of pre-test was 58,94 .

Table 1. Students Pre-Test Score

\begin{tabular}{|c|c|}
\hline Name & Pre-Test \\
\hline Student 1 & 56 \\
\hline Student 2 & 44 \\
\hline Student 3 & 44 \\
\hline Student 4 & 44 \\
\hline Student 5 & 44 \\
\hline Student 6 & 48 \\
\hline Student 7 & 72 \\
\hline Student 8 & 44 \\
\hline Student 9 & 72 \\
\hline Student 10 & 64 \\
\hline Student 11 & 60 \\
\hline Student 12 & 80 \\
\hline Student 13 & 72 \\
\hline Student 14 & 56 \\
\hline Student 15 & 60 \\
\hline Student 16 & 40 \\
\hline Student 17 & 40 \\
\hline Student 18 & 72 \\
\hline Student 19 & 60 \\
\hline Student 20 & 40 \\
\hline Student 21 & 60 \\
\hline Student 22 & 80 \\
\hline Student 23 & 60 \\
\hline Student 24 & 72 \\
\hline Student 25 & 64 \\
\hline Student 26 & 64 \\
\hline Student 27 & 76 \\
\hline Student 28 & 64 \\
\hline Student 29 & 68 \\
\hline Student 30 & 28 \\
\hline Student 31 & 76 \\
\hline Student 32 & 56 \\
\hline Student 33 & 64 \\
\hline Student 34 & 60 \\
\hline $\mathrm{N}=34$ & 2004 \\
\hline
\end{tabular}

\section{The Result of Post-test}

Post-test was a test that was given after being given treatment to the students and applied socrative. Post-test was attended 34 students. The writer gave a post-test consisted 25 questions. The posttest material and question was same as the pre-test. The total results of the post-test score were 3240 out of 34 students. The mean of post-test was 95 .

Table 2. Students Post-Test Score

\begin{tabular}{ll}
\hline Name & Post-Test \\
\hline Student 1 & 100 \\
Student 2 & 60 \\
Student 3 & 100 \\
Student 4 & 88 \\
Student 5 & 92 \\
Student 6 & 92 \\
Student 7 & 96 \\
Student 8 & 88 \\
Student 9 & 92 \\
Student 10 & 100 \\
Student 11 & 100 \\
Student 12 & 100 \\
Student 13 & 100 \\
Student 14 & 88 \\
Student 15 & 100 \\
Student 16 & 100 \\
Student 17 & 100 \\
Student 18 & 100 \\
Student 19 & 100 \\
Student 20 & 92 \\
Student 21 & 88 \\
Student 22 & 100 \\
Student 23 & 100 \\
Student 24 & 100 \\
Student 25 & 92 \\
Student 26 & 100 \\
Student 27 & 96 \\
Student 28 & 92 \\
Student 29 & 96 \\
Student 30 & 88 \\
Student 31 & 100 \\
Student 32 & 100 \\
Student 33 & 100 \\
Student 34 & 100 \\
N =34 & 3240 \\
\hline & \\
& \\
& \\
\hline
\end{tabular}

\section{Data Analysis}

Find the mean of Difference, by the formula:

$$
\begin{aligned}
M_{D} & =\frac{\sum D}{N} \\
& =\frac{-1236}{34} \\
& =36,35
\end{aligned}
$$


Looking for standard deviations from

Difference $\left(\mathrm{SD}_{\mathrm{D}}\right)$, by the formula:

$$
\begin{aligned}
& S D_{D}=\sqrt{\frac{\sum_{D} 2}{N}-\left(\frac{\sum D}{N}\right)^{2}} \\
& =\sqrt{\frac{50032}{34}-\left(\frac{-1236}{34}\right)^{2}} \\
& =\sqrt{1471,53-(-36,35)^{2}} \\
& =\sqrt{1471,53-1321,32} \\
& =\sqrt{150,21} \\
& =12,256
\end{aligned}
$$

Looking for the standard error of the mean of difference, which is $S E_{M D}$ using the formula:

$$
\begin{array}{r}
S E_{M D}=\frac{S D_{D}}{\sqrt{N-1}} \\
=\frac{12,256}{\sqrt{34-1}} \\
=\frac{12,256}{\sqrt{33}} \\
=\frac{12,256}{5,745} \\
=2,13
\end{array}
$$

Looking for $\mathrm{t}_{\mathrm{o}}$, by the formula:

$t_{o}=\frac{M_{D}}{S E_{M D}}$

$=\frac{36,35}{2,13}$

$=17,07$

After all the result of t-test, the writer calculated Degree of Freedom (df) by the number of each object $(\mathrm{N})$ less one numeral. The writer was consulted at the table critical value and t-value at the level significances 0,05 the respondents of this research were 34 students, it means that degree of freedom (df) was determined by $\mathrm{N}-1$, were $\mathrm{N}$ represented the sum of respondents. And the "df" was $34-1=$ 33, the t-value at critical table of 0,05 was 2,03 at the level significance 0,05 for $\mathrm{df}=$

\begin{tabular}{|c|c|c|c|}
\hline \multirow{2}{*}{$\begin{array}{l}\text { Degree of } \\
\text { Freedom }(\mathrm{df})\end{array}$} & \multicolumn{2}{|c|}{$\mathrm{t}$} & \multirow[t]{2}{*}{ Note } \\
\hline & \multicolumn{2}{|r|}{,05 } & \\
\hline $\mathrm{N}-1$ & \multicolumn{2}{|c|}{1} & $\mathrm{t}-$ \\
\hline $34-1$ & 7,07 & ,03 & \\
\hline 33 & & & $\begin{array}{l}\text { t-table, so } \\
\text { alternative } \\
\text { hypothesis }\end{array}$ \\
\hline
\end{tabular}
33. Therefore, the influence of using socrative on reading ability of the students computer and network technique at SMKN 1 Baureno in the academic year 2019/2020 was effective. It means that there was significance different of the students' reading ability. So that, the alternative hypothesis $\left(\mathrm{H}_{\mathrm{a}}\right)$ was accepted and the null hypothesis $\left(\mathrm{H}_{\mathrm{o}}\right)$ was rejected.

Table 3. The Hypothesis Testing of Test 
learning to be used learning reading especially present continuous.

\section{The Result of Questionnaire}

Questionnaire consists of 5 numbers of items, it is answered by 34 students. After collecting the result of questionnaire that is diagramed using pie diagram. It is analyzed by diagraming the students' answer by using Guttman scale.

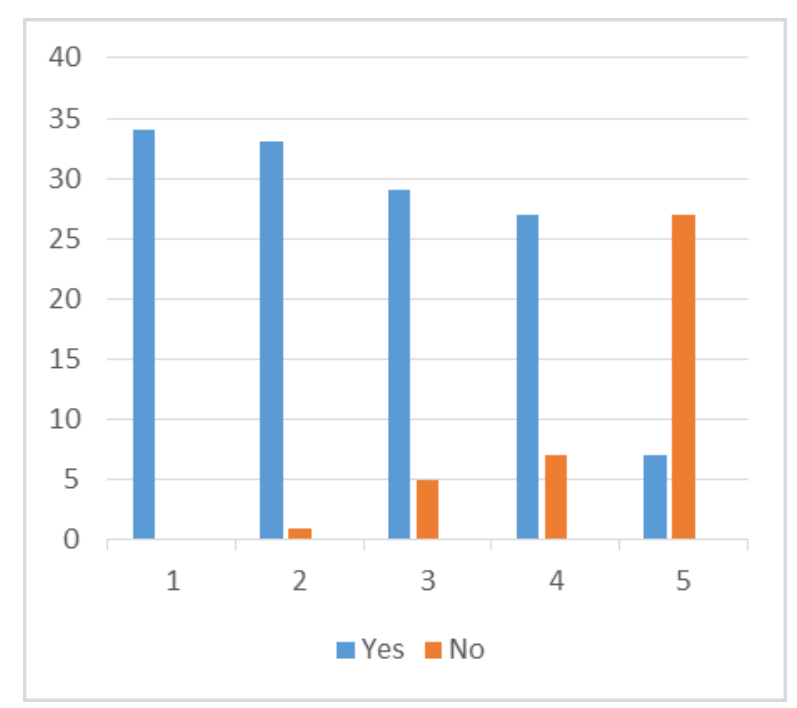

Figure 1. Graphic of Questionnaire

Based on all the questionnaire, the writer can conclude that socrative is very effective to be applied at SMKN 1 Baureno exactly to the computer and network technique students. Most all students think that socrative is effective e-

\section{CONCLUSION}

Based on the research data after doing pre-test, treatment and post-test. The t-test result from 34 student respondents is 17,07. Siginificant point t-table used in this study is 0,05 . So, the t-test value is higher than degree of freedom and t-table. It means that there is significance different of students' ability. So that, the alternative hypothesis $\left(\mathrm{H}_{\mathrm{a}}\right)$ is accepted and the null hypothesis $\left(\mathrm{H}_{\mathrm{o}}\right)$ is rejected. So, socrative is effective to improve tenth grade computer and network technique students' reading ability in SMKN 1 Baureno.

Based on the result of questionnaire, the researcher can conclude that all the students, consisting of 17 males and 17 females at SMKN 1 Baureno, choose reading using socrative than reading using offline. They think that socrative is fun for learning reading. Learning using socrative also can make 
easier and more creative to understand and make present continuous sentence. And the last is the students do not have any difficulty in learning reading using socrative.

To sum up, socrative can help teacher and students to make easier on learning reading. It can be their media on learning reading.

\section{REFERENCES}

Arikunto, S. (2006). Prosedur Penelitian Suatu Pendekatan Praktik. Jakarta: Rineka Cipta.

Cahyani, I. (2009). Pembelajaran Bahasa Indonesia. Jakarta: Direktorat Jendral Pendidikan Islam Departemen Agama RI.
Harras, K. A. (2011). Hakekat Membaca. Jakarta: Depdikbud PPGLTP.

Indayatun, S. (2014). Practical Grammar Understanding Completed With Reading Texts. Kediri: CV Jenggala.

Rahim, F. (2008). Pengajaran Membaca di Sekolah Dasar. Jakarta : Bumi Aksara.

Setyanto, A. E. (2013). Memperkenalkan Kembali Metode Eksperimen Dalam Kajian Komunikasi. http://ojs.uajy.ac.id, 3.

Somadayo, S. (2011). Strategi dan Teknik Pembelajaran Membaca. Yogyakarta: Graha Ilmu.

Sudijono, A. (2014). Pengantar Statistik Pendidikan. Jakarta: PT Raja Grafindo Persada.

Sugiyono. (2016). Metode Penelitian Kuantitatif Kualitatif dan $R \& D$. Bandung: Alfabeta CV.

Sukmadinata, N. S. (2013). Metode Peneletian Pendidikan. Bandung: PT Remaja Rosdakarya. 